\title{
Infection Status with Clinostomum complanatum Metacercariae in Fish from Water Systems of Nakdong-gang (River) in Korea
}

\author{
Woon-Mok Sohn",*, Byoung-Kuk Na', Shin-Hyeong $\mathrm{Cho}^{2}$ \\ ${ }^{1}$ Department of Parasitology and Tropical Medicine, and Institute of Health Sciences, Gyeongsang National University College of Medicine, \\ Jinju 52727, Korea; '2Division of Vectors and Parasitic Diseases, Centers for Disease Control and Prevention, Osong 28159, Korea
}

\begin{abstract}
The infection status of Clinostomum complanatum metacercariae (CcMc) was broadly surveyed in fishes from water systems of Nakdong-gang (River) in the Republic of Korea (Korea) for 5 years. All 4,468 fishes collected were individually examined by the artificial digestion methods. No CcMc were detected in fishes from Naeseongcheon in Yecheongun, Gigyecheon in Gyeongju-si, Gyeongsangbuk-do, and Hamancheon in Haman-gun, Gyeongsangnam-do. In fishes from Wicheon in Gunwi-gun, Gyeongsangbuk-do, CcMc were detected in 180 (15.4\%) out of 1,168 fishes and their intensity was 5.8 per fish infected. The prevalences with $\mathrm{CcMc}$ in positive fish species from 3 other surveyed areas, i.e., Banbyeoncheon in Yeongyang-gun, Nakdong-gang in Sangju-si and Hoecheon in Goryeong-gun, in Gyeongsangbuk-do were 19.3\%, 33.3\%, and 19.0\% and their intensities were 1.5, 17.6, and 2.6 per fish infected respectively. In fishes from Yangcheon in Sancheong-gun, Gyeongsangnam-do, CcMc were detected in 811 (45.6\%) out of 1,779 fishes examined and their intensity was 9.8 per fish infected. The prevalence was most high in Squalidus spp. (97.7\%) and followed by acheilognathinid fish (66.8\%), Pungtungia herzi (52.0\%), rasborinid fish (39.6\%) and Hemibarbus spp. (25.9\%) from Yangcheon. The intensity was also most high in Squalidus spp. (27.0). The endemicity with CcMc was very low in fishes from water systems of Nakdong-gang in the east coast of Korea. Conclusively, it is confirmed that various fish species act as the second intermediate hosts of $C$. complanatum, and the endemicities of CcMc are more or less different by the fish species and group from Yangcheon, in Sancheong-gun, Gyeongsangnam-do, Korea
\end{abstract}

Key words: Clinostomum complanatum, metacercaria, Nakdong-gang, Yangcheon

\section{INTRODUCTION}

Clinostomum complanatum (Digenea: Clinostomidae) is a laryngial fluke in avian and mammarian hosts. This species of trematode is sometimes to be infected in humans through the consumption of raw fish meat. More than 25 human cases were mainly reported in Japan and the Republic of Korea (Korea) [1-8]. In Korea, total 6 cases were reported since the first occurrence in 1994 [3-8].

Clinostomum spp. laryngial flukes commonly have 2 intermediate hosts in the life cycle. The freshwater snails in the family Lymnaeidae, i.e., Lymnaea spp. and Radix spp., serve as the first intermediate hosts, and freshwater and brackish water fish act

\footnotetext{
- Received 20 May 2019, revised 30 July 2019, accepted 7 August 2019.

*Corresponding author (wmsohn@gnu.ac.kr)

(C) 2019, Korean Society for Parasitology and Tropical Medicine

This is an Open Access article distributed under the terms of the Creative Commons

Attribution Non-Commercial License (http://creativecommons.org/licenses/by-nc/4.0) which permits unrestricted non-commercial use, distribution, and reproduction in any

medium, provided the original work is properly cited.
}

as the second intermediate hosts. In Korea, Chung et al. [9] recorded 12 species of freshwater fishes as the second intermediate hosts of C. complanatum, and Chung et al. [10] also described the cercariae and redia of $C$. complanatum, which were detected in Radix auricularia coreana from a pond, an enzootic focus of this trematode, in Uiseong-gun (gun=county), Gyeongsangbuk-do (do=Province). Rim et al. [11] detected $C$. complanatum metacercariae (CcMc) in 2 fish species, i.e., Pseudorasbora parva and Squalidus chankaensis tsuchigae, from the streams of Taewha-gang (gang means river) and Hyeongsangang located in the southeast regions of Korea. Recently, Sohn et al. [12] found CcMc in 2 fish species, Punctungia herzi and Hemibarbus longirostris, from Chatancheon (a stream of Hantangang) in Yeoncheon-gun, Gyeonggi-do.

On the other hand, the infection status of zoonotic trematode metacercariae (ZTM) in the second intermediate hosts are used as the important epidemiological indices. Thus, many Korean workers have investigated the infection status with ZTM in fishes from various endemic areas to estimate the en- 
demicities of specific zoonotic trematode, i.e., Clonorchis sinensis, Metagonimus spp. including M. yokogawai, Centrocestus armatus and Isthmiophora hortensis, infections [13-19]. However, the infection status of CcMc was rarely surveyed and has not been broadly investigated in freshwater fish from the water systems of Korea. Therefore, in the present study, we are going to investigate the infection status of CcMc in freshwater fish from the water systems of Nakdong-gang in Korea.

\section{MATERIALS AND METHODS}

\section{Fish collection (Fig. 1)}

Water systems of Nakdong-gang in Gyeongsangbuk-do:
Fishes from Naeseongcheon (1) in Fig. 1) in Yecheon-gun (2014: 103 fishes in 15 spp.), Banbyeoncheon (2) in Yeongyang-gun (2015: 161 fishes in 12 spp.), Wicheon (3) in Gunwi-gun (2013: 107 fishes in 12 spp.; 2014: 338 fishes in 24 spp.; 2015: 245 fishes in 19 spp.; 2016: 279 fishes in 24 spp.; 2017: 199 fishes in 17 spp.) Nakdong-gang (4) in Sangju-si (si=city), (2017: 143 fishes in 14 spp.) and Hoecheon (5) in Goryeong-gun (2013: 165 fishes in 13 spp.) were examined.

Water systems of Nakdong-gang in Gyeongsangnam-do: Fishes from Yangcheon (6) in Sancheong-gun (2013: 644 fishes in 20 spp.; 2014: 291 fishes in 14 spp.; 2015: 183 fishes in 15 spp.; 2016: 253 fishes in 16 spp.; 2017: 408 fishes in 22 spp.), Jisucheon (7) in Jinju-si (2014: 94 fishes in 11 spp.)

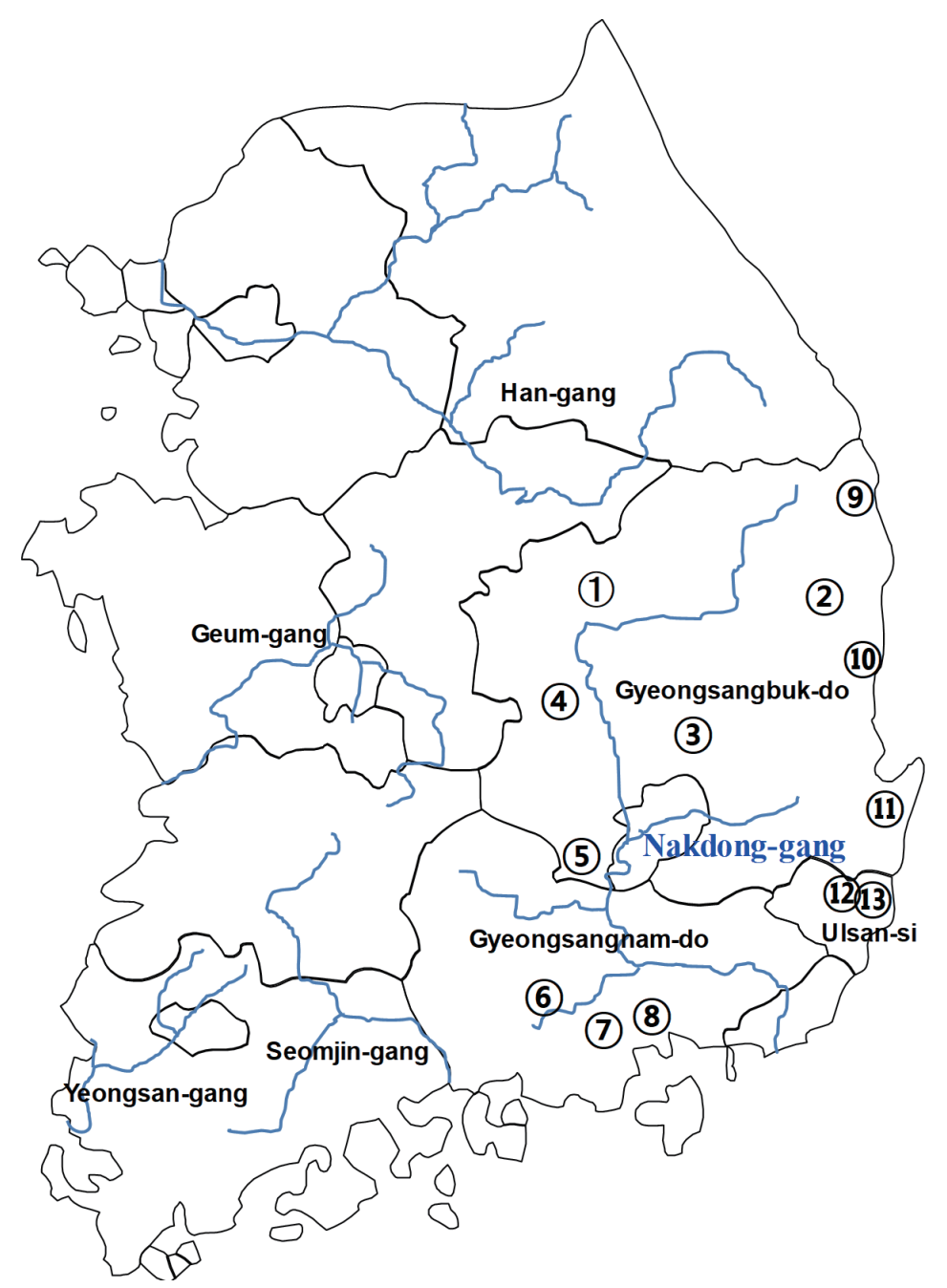

Fig. 1. Surveyed areas in water syatems of Nakdong-gang (River) in Korea: (1) Naeseongcheon in Yecheon-gun, (2) Banbyeoncheon in Yeongyang-gun, (3) Wicheon in Gunwi-gun, (4) Nakdong-gang in Sangju-si, (5) Hoecheon in Goryeong-gun, Gyeongsangbuk-do, (6) Yangcheon in Sancheong-gun, (7) Yeongdeok in Jinju-si, (8) Hamancheon in Haman-gun, Gyeongsangnam-do, (9) Wangpicheon in Uljin-gun, (10) Osipcheon in Yeongdeok-gun, (11) Gigyecheon in Gyeongju-si, Gyeongsangbuk-do, (12) Cheokgwacheon, and (13) Taehwagang in Ulsan-si (Metropolitan City). 
and Hamancheon (8) in Haman-gun (2014: 73 fishes in 9 spp.) were examined.

Water systems of Nakdong-gang in the east coast of Korea: Fishes from Wangpicheon (9) in Uljin-gun (2015: 239 fishes in 13 spp.), Osipcheon (10) in Yeongdeok-gun (2015: 122 fishes in 11 spp.) and Gigyecheon (11) in Gyeongju-si (2015: 111 fishes in 11 spp.), Gyeongsangbuk-do, Cheokgwacheon (12) (2015: 221 fishes in 10 spp.) and Taehwagang (13) (2015: 89 fishes in 14 spp.) in Ulsan Metropolitan City were examined.

\section{Examination methods}

All collected fishes with ice were transferred to the laboratory of the Department of Parasitology and Tropical Medicine, Gyeongsang National University College of Medicine, Jinju, Korea. After the identification of fish species, they were individually ground with a mortar. Each ground fish meat was mixed with artificial gastric juice and the mixture was incubat-

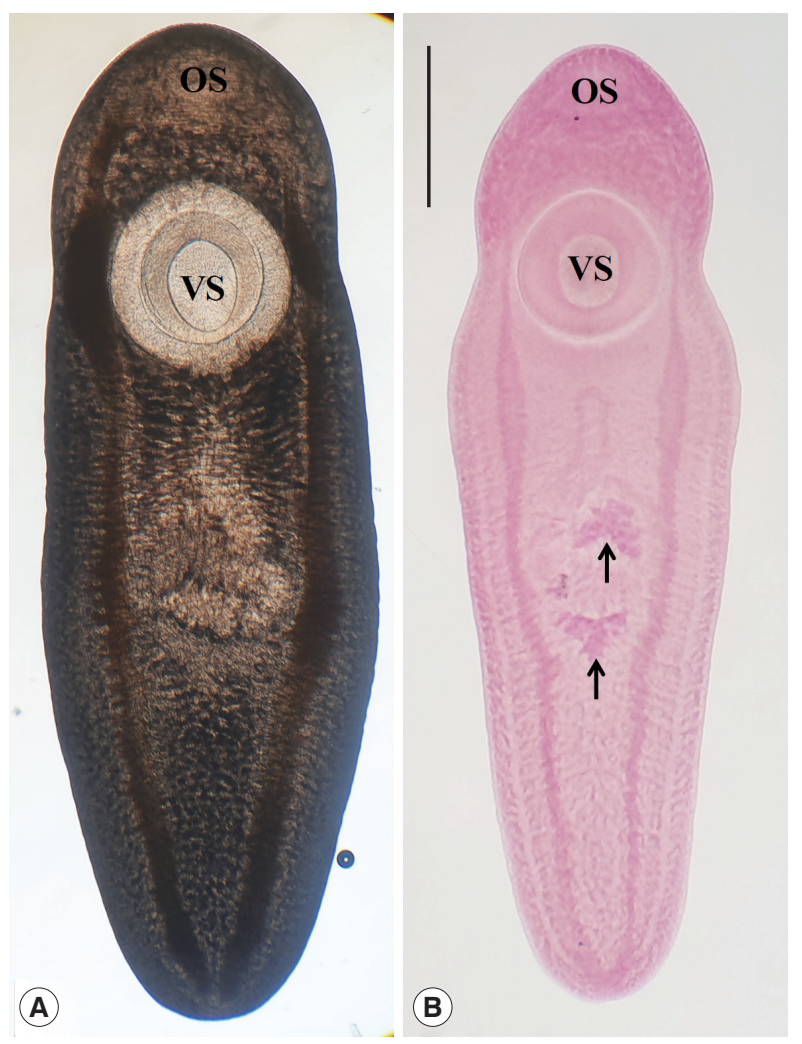

Fig. 2. Metacercariae of Clinostomum complanatum collected in Squalidus japonicus coreanus from Yangcheon in Sancheonggun, Gyeongsangnam-do. (A) A fresh unstained metacercaria shows the intestinal ceca with characteristic contents. (B) A metacercaria stained with Semichon's acetocarmin, which has the larger ventral sucker (VS) closely located to the oral sucker (OS) and the primordia of testes (arrows). The scale bar is $1 \mathrm{~mm}$. ed at $36^{\circ} \mathrm{C}$ for $2 \mathrm{hr}$. The digested material of each fish was washed with $0.85 \%$ saline until the supernatant is cleared and examined with naked eyes and under a stereomicroscope. The excysted CcMc (Fig. 2) were separately collected [20] and were counted to get hold of infection rates (\%) and densities (No. of CcMc per fish infected) by fish species.

\section{RESULTS}

\section{Infection status with CcMc in fish from Nakdong-gang in Gyeongsangbuk-do}

No CcMc were detected in fishes from Naeseongcheon in Yecheon-gun. In fishes from Wicheon in Gunwi-gun, CcMc were detected in 180 (15.4\%) out of 1,168 fishes and their intensity was 5.8 per fish infected. The prevalences by the year examined were $15.0-27.0 \%$ (20.5\% in average) in the positive fish species from Wicheon. The infection status with CcMc by the fish species and examined year in Wicheon was detailedly shown in Table 1. In positive fish species from another surveyed areas, i.e., Banbyeoncheon in Yeongyang-gun, Nakdonggang in Sangju-si and Hoecheon in Goryeong-gun, the prevalence with CcMc was $23.8 \%$ in average and their intensity was 9.2 per fish infected. The infection status with CcMc by the fish species and survey areas was detailedly revealed in Table 2.

\section{Infection status with CcMc in fish from Nakdong-gang in Gyeongsangnam-do}

No CcMc were detected in fishes from Hamancheon in Haman-gun. In fishes from Yangcheon in Sancheong-gun, CcMc were detected in 811 (45.6\%) out of 1,779 fishes examined and their intensity was 9.8 per fish infected. The prevalences by the year examined were $38.6-62.8 \%$ (51.4\% in average) in the positive fish species from Yangcheon. The infection status with CcMc by the fish species and examined year in Yangcheon was detailedly designated in Table 3. Only one CcMc was found in a $S$. gracilis majimae from Jisucheon in Jinju-si. The infection tendency with CcMc by the fish groups was somewhat revealed in fishes from Yangcheon. The prevalence was most high in Squalidus spp. (97.7\%) and followed by acheilognathinid fish $(66.8 \%)$, P. herzi (52.0\%), rasborinid fish (39.6\%) and Hemibarbus spp. (25.9\%). The intensity was also most high in Squalidus spp. (27.0) and followed by acheilognathinid fish (8.9), P. herzi (6.6), rasborinid fish (3.7) and Hemibarbus spp. (2.5) (Table 4). 
Table 1. Infection status of Clinostomum complanatum metacercariae by the fish species and examined year in Wicheon in Gunwi-gun, Gyeongsangbuk-do, Korea

\begin{tabular}{|c|c|c|c|c|}
\hline \multirow{2}{*}{ Year and fish examined } & \multirow{2}{*}{ No. of fish examined } & \multirow{2}{*}{ No. of fish infected (\%) } & \multicolumn{2}{|c|}{ No. of CcMc detected } \\
\hline & & & Range & Average \\
\hline \multicolumn{5}{|l|}{2013} \\
\hline Pungtungia herzi & 20 & $1(5.0)$ & - & 2.0 \\
\hline Acheilognathus koreensis & 10 & $4(40.0)$ & $1-7$ & 3.5 \\
\hline Squalidus gracilis majimae & 9 & $3(33.3)$ & - & 1.0 \\
\hline Subtotal & 39 & $8(20.5)$ & $1-7$ & 2.4 \\
\hline \multicolumn{5}{|l|}{2014} \\
\hline Zacco platypus & 60 & $4(6.7)$ & $1-7$ & 3.0 \\
\hline Zacco temminckii & 50 & $2(4.0)$ & $1-3$ & 2.0 \\
\hline Pungtungia herzi & 47 & $16(34.0)$ & $1-34$ & 7.1 \\
\hline Acheilognathus koreensis & 29 & $13(44.8)$ & $1-32$ & 6.1 \\
\hline Acheilognathus yamatsutae & 25 & $1(4.0)$ & - & 1.0 \\
\hline Squalidus japonicus coreanus & 14 & $11(78.6)$ & $1-48$ & 7.9 \\
\hline Carassius auratus & 13 & $1(7.7)$ & - & 2.0 \\
\hline Squalidus gracilis majimae & 13 & $2(15.4)$ & - & 1.0 \\
\hline Subtotal & 251 & $50(19.9)$ & $1-48$ & 6.0 \\
\hline \multicolumn{5}{|l|}{2015} \\
\hline Zacco platypus & 50 & $2(4.0)$ & $2-7$ & 4.5 \\
\hline Zacoo temminckii & 49 & $1(2.0)$ & - & 1.0 \\
\hline Pungtungia herzi & 41 & 8 (19.5) & $1-11$ & 3.6 \\
\hline Acheilognathus koreensis & 29 & $20(69.0)$ & $1-20$ & 4.3 \\
\hline Acheilognathus yamatsutae & 16 & $1(6.3)$ & - & 1.0 \\
\hline Squalidus japonicus coreanus & 15 & $4(26.7)$ & $8-47$ & 21.0 \\
\hline Squalidus gracilis majimae & 11 & $4(36.4)$ & $1-16$ & 5.8 \\
\hline Abbottina springeri & 4 & $1(25.0)$ & - & 3.0 \\
\hline Subtotal & 215 & $41(19.1)$ & $1-47$ & 5.7 \\
\hline \multicolumn{5}{|l|}{2016} \\
\hline Zacco platypus & 63 & $1(1.6)$ & - & 5.0 \\
\hline Acheilognathus koreensis & 55 & $31(56.4)$ & $1-27$ & 5.1 \\
\hline Pungtungia herzi & 38 & $11(28.9)$ & $1-8$ & 2.8 \\
\hline Acheilognathus yamatsutae & 29 & $2(6.9)$ & $2-4$ & 3.0 \\
\hline Acheilognathus rhombeus & 15 & $7(46.7)$ & $1-3$ & 2.1 \\
\hline Squalidus japonicus coreanus & 9 & $3(33.3)$ & $8-34$ & 19.0 \\
\hline Squalidus gracilis majimae & 2 & $2(100)$ & $5-59$ & 32.0 \\
\hline Subtotal & 211 & $57(27.0)$ & $1-59$ & 5.9 \\
\hline \multicolumn{5}{|l|}{2017} \\
\hline Zacco platypus & 50 & $3(6.0)$ & $2-3$ & 2.3 \\
\hline Squalidus japonicus coreanus & 31 & $7(22.6)$ & $1-33$ & 8.6 \\
\hline Acheilognathus yamatsutae & 27 & $2(7.4)$ & - & 1.0 \\
\hline Pungtungia herzi & 26 & $5(19.2)$ & $1-13$ & 4.6 \\
\hline Acheilognathus koreensis & 26 & $7(26.9)$ & $1-42$ & 8.6 \\
\hline Subtotal & 160 & $24(15.0)$ & $1-42$ & 6.3 \\
\hline Total & 876 & $180(20.5)$ & $1-59$ & 5.8 \\
\hline
\end{tabular}

\section{Infection status with CcMc in fish from the streams in the} east coast

No CcMc were detected in fishes from Gigyecheon (a branch of Hyeongsangang) in Gyeongju-si, Gyeongsangbukdo. In fishes from water systems of Nakdong-gang in the east coast of Korea, the endemicity with CcMc was very low. The infection status with CcMc by the survey areas and fish species examined was detailedly revealed in Table 5.

\section{DISCUSSION}

In the present study, CcMc were found in total 23 species of 
Table 2. Infection status of Clinostomum complanatum metacercariae by the species of fish from water systems of Nakdong-gang in Gyeongsangbuk-do

\begin{tabular}{|c|c|c|c|c|}
\hline \multirow{2}{*}{ Locality and fish sp. } & \multirow{2}{*}{ No. of fish examined } & \multirow{2}{*}{ No. of fish infected (\%) } & \multicolumn{2}{|c|}{ No. of CcMc detected } \\
\hline & & & Range & Average \\
\hline \multicolumn{5}{|l|}{ Banbyeoncheon in Yeongyang-gun } \\
\hline Pungtungia herzi & 26 & $2(7.7)$ & $1-2$ & 1.5 \\
\hline Acheilognathus koreensis & 18 & $7(38.9)$ & $1-5$ & 1.6 \\
\hline Squalidus gracilis majimae & 8 & $1(12.5)$ & - & 1.0 \\
\hline Abbottina springeri & 5 & $1(20.0)$ & - & 1.0 \\
\hline Subtotal & 57 & $11(19.3)$ & $1-5$ & 1.5 \\
\hline \multicolumn{5}{|l|}{ Nakdonggang in Sangju-si } \\
\hline Acheilognathus lanceolatus & 31 & $9(29.0)$ & $1-11$ & 4.0 \\
\hline Carassius auratus & 9 & $2(22.2)$ & $86-147$ & 116.5 \\
\hline Acheilognathus rhombeus & 9 & $5(55.6)$ & $3-26$ & 11.6 \\
\hline Hemibarbus labeo & 6 & $1(16.7)$ & - & 4.0 \\
\hline Hemibarbus longirostris & 2 & $2(100)$ & $1-2$ & 1.5 \\
\hline Subtotal & 57 & 19 (33.3) & $1-147$ & 17.6 \\
\hline \multicolumn{5}{|l|}{ Hoecheon in Goryeong-gun } \\
\hline Hemiculter eigenmanni & 34 & $3(8.8)$ & $1-3$ & 1.7 \\
\hline Pseudorasbora parva & 16 & $5(31.3)$ & $1-10$ & 3.2 \\
\hline Hemibarbus labeo & 7 & $2(28.6)$ & - & 3.0 \\
\hline Squalidus japonicus coreanus & 1 & $1(100)$ & - & 1.0 \\
\hline Subtotal & 58 & $11(19.0)$ & $1-10$ & 2.6 \\
\hline Total & 172 & $41(23.8)$ & $1-147$ & 9.2 \\
\hline
\end{tabular}

freshwater fishes from the water systems of Nakdong-gang in Korea. Among these fish hosts, 10 ones, A. koreensis, A. rhombeus, A. yamatsutae, C. auratus, H. longirostris, P. parva, P. herzi, S. chankaesis tsuchigae, $S$. gracilis maejimae, and Z. temminkii, have been previously reported in Korea $[9,11,12]$. Therefore, a total of 26 fish species including 3 ones, Cobitis sinensis, Microphysogobio yaluensis and Rhodeus uyekii, formerly reported in Chung et al. [9] are to be listed as the second intermediate hosts of $C$. complanatum in Korea. In Japan, less than 8 fish species, i.e., Carassius spp. including C. auratus, Cyprinus carpio, P. parva, Pseudogobio esocinus, Rhodeus ocellatus, and R. lanceolatus (syn. Acheilognathus lanceolatus), were reported as the second intermediate hosts of C. complanatum until 1992 [21].

The prevalence of CcMc was most high in the positive fish group from Yangcheon (51.4\%) in Sancheong-gun, Gyeongsangnam-do, followed by that from Nakdong-gang (33.3\%) in Sangju-si, Gyeongsangbuk-do, and those from remain other areas were relatively low (7.1-20.5\%). Even no CcMc were detected in fishes from 3 survey areas, Naeseongcheon in Yecheon-gun, Gigyecheon in Gyeongju-si, Gyeongsangbuk-do and Hamancheon in Haman-gun, Gyeongsangnam-do. The intensity of infection with CcMc was most high in the positive fish group from Nakdong-gang (17.6 per fish infected) in
Sangju-si, followed by that from Yangcheon (9.8) in Sancheong-gun, and those from remain other areas were relatively low (1.0-5.8). The reason why the more higher intensity in fish from Nakdong-gang in Sangju-si is 2 crucian carps, C. auratus, heavily infected (86 and $147 \mathrm{CcMc}$ ). Above findings suggested that the endemicities of CcMc are relatively high in fish from Yangcheon in Sancheong-gun and Nakdong-gang in Sangju-si, and relatively low in fish from other areas like in previous studies in Korea $[9,11,12]$.

In the highly endemic area of CcMc, Yangcheon in Sancheong-gun, Gyeongsangnam-do, the endemicity was revealed a certain tendency by the subfamily groups in cyprinid fish. The endemicity (average CcMc intensity $\times$ prevalence/100) was 8.47 in gobioninid (Gobioninae) fish group, i.e., Squalidus spp., P. herzi and Hemibarbus spp., 5.95 in acheilognathinid (Acheilognathininae) fish, Acanthorhodeus spp. and Acheilognathus spp., and 1.47 in rasborinid (Rasborininae) fish group, Zacco spp. The endemicity in the gobioninid fish was most high in Squalidus spp., 26.38, followed by in P. herzi, 3.43, and in Hemibarbus spp., 0.65. From the above findings, we could know that the susceptibility of C. complanatum cercariae is relatively high in Squalidus spp. and the endemicities of CcMc are more or less different by the fish group and species from Yang- 
Table 3. Infection status of Clinostomum complanatum metacercariae by the fish species and examined year in Yangcheon in Sancheong-gun, Gyeongsangnam-do, Korea

\begin{tabular}{|c|c|c|c|c|}
\hline \multirow{2}{*}{ Year and fish examined } & \multirow{2}{*}{ No. of fish examined } & \multirow{2}{*}{ No. of fish infected (\%) } & \multicolumn{2}{|c|}{ No. of CcMc detected } \\
\hline & & & Range & Average \\
\hline $\begin{array}{l}2013 \\
\text { Pungtungia herzi } \\
\text { Zacco koreanus } \\
\text { Acheilognathus majusculus } \\
\text { Zacco platypus } \\
\text { Squalidus chankaensis } \\
\text { Hemibarbus longirostris } \\
\text { Acheilognathus koreensis } \\
\text { Squalidus japonicus coreanus } \\
\text { Carassius auratus } \\
\text { Acanthorhodeus gracilis } \\
\text { Acanthorhodeus macropterus } \\
\text { Acheilognathus rhombeus } \\
\text { Acheilognathus yamatsutae } \\
\text { Subtotal }\end{array}$ & $\begin{array}{r}142 \\
94 \\
85 \\
55 \\
51 \\
34 \\
31 \\
30 \\
20 \\
20 \\
17 \\
8 \\
1 \\
588\end{array}$ & $\begin{array}{c}86(60.6) \\
49(52.1) \\
66(77.6) \\
35(63.6) \\
51(100) \\
7(20.6) \\
28(90.3) \\
30(100) \\
5(25.0) \\
5(25.0) \\
1(5.9) \\
5(62.5) \\
1(100) \\
369(62.8)\end{array}$ & $\begin{array}{l}1-34 \\
1-22 \\
1-22 \\
1-8 \\
1-143 \\
1-5 \\
1-14 \\
2-46 \\
1-5 \\
1-6 \\
- \\
1-7 \\
- \\
1-143\end{array}$ & $\begin{array}{r}5.9 \\
3.3 \\
6.8 \\
2.9 \\
32.6 \\
1.9 \\
6.5 \\
19.5 \\
2.4 \\
3.2 \\
1.0 \\
2.2 \\
5.0 \\
10.0\end{array}$ \\
\hline $\begin{array}{l}2014 \\
\text { Pungtungia herzi } \\
\text { Acheilognathus majusculus } \\
\text { Zacco koreanus } \\
\text { Coreoperca herzi } \\
\text { Zacco platypus } \\
\text { Squalidus japonicus coreanus } \\
\text { Acheilognathus koreensis } \\
\text { Odontobutis platycephala } \\
\text { Acheilognathus yamatsutae } \\
\text { Hemibarbus longirostris } \\
\text { Subtotal }\end{array}$ & $\begin{array}{r}65 \\
40 \\
40 \\
30 \\
25 \\
25 \\
13 \\
13 \\
10 \\
7 \\
268\end{array}$ & $\begin{aligned} & 31(47.7) \\
& 22(55.0) \\
& 15(37.5) \\
& 2(6.7) \\
& 10(40.0) \\
& 25(100) \\
& 10(76.9) \\
& 2(15.4) \\
& 7(70.0) \\
& 2(28.6) \\
& 126(47.0)\end{aligned}$ & $\begin{array}{l}1-14 \\
1-18 \\
1-6 \\
- \\
1-6 \\
7-67 \\
1-17 \\
5-10 \\
1-6 \\
- \\
1-67\end{array}$ & $\begin{array}{r}63.1 \\
3.5 \\
1.9 \\
1.0 \\
2.8 \\
23.2 \\
7.4 \\
7.5 \\
2.9 \\
1.0 \\
7.3\end{array}$ \\
\hline $\begin{array}{l}2015 \\
\text { Pungtungia herzi } \\
\text { Zacoo temminckii } \\
\text { Zacco platypus } \\
\text { Hemibarbus longirostris } \\
\text { Acheilognathus majusculus } \\
\text { Acheilognathus koreensis } \\
\text { Acheilognathus yamatsutae } \\
\text { Squalidus japonicus coreanus } \\
\text { Subtotal }\end{array}$ & $\begin{array}{r}40 \\
40 \\
40 \\
25 \\
9 \\
7 \\
3 \\
2 \\
166\end{array}$ & $\begin{array}{r}19(47.5) \\
8(20.0) \\
20(50.0) \\
6(24.0) \\
2(22.2) \\
7(100) \\
1(33.3) \\
1(50.0) \\
64(38.6)\end{array}$ & $\begin{array}{c}1-45 \\
1-12 \\
1-22 \\
1-4 \\
14-40 \\
3-74 \\
- \\
- \\
1-74\end{array}$ & $\begin{array}{r}9.9 \\
4.1 \\
5.2 \\
3.3 \\
27.0 \\
16.1 \\
1.0 \\
12.0 \\
8.2\end{array}$ \\
\hline $\begin{array}{l}2016 \\
\text { Acheilognathus koreensis } \\
\text { Pungtungia herzi } \\
\text { Zacco platypus } \\
\text { Acheilognathus majusculus } \\
\text { Carassius auratus } \\
\text { Zacco temminckii } \\
\text { Zacco koreanus } \\
\text { Acheilognathus rhombeus } \\
\text { Acheilognathus yamatsutae } \\
\text { Squalidus japonicus coreanus } \\
\text { Hemibarbus longirostris } \\
\text { Subtotal }\end{array}$ & $\begin{array}{r}40 \\
33 \\
32 \\
23 \\
22 \\
21 \\
20 \\
20 \\
13 \\
5 \\
4 \\
233\end{array}$ & $\begin{array}{c}34(85.0) \\
13(39.4) \\
9(28.1) \\
15(65.2) \\
1(4.5) \\
2(9.5) \\
11(55.0) \\
15(75.0) \\
9(69.2) \\
5(100) \\
1(25.0) \\
115(49.4)\end{array}$ & $\begin{array}{l}1-25 \\
1-8 \\
1-10 \\
1-16 \\
- \\
1-3 \\
1-8 \\
1-13 \\
1-14 \\
6-64 \\
- \\
1-64\end{array}$ & $\begin{array}{r}6.2 \\
2.8 \\
3.2 \\
4.1 \\
1.0 \\
2.0 \\
3.7 \\
5.1 \\
4.6 \\
28.8 \\
7.0 \\
5.7\end{array}$ \\
\hline $\begin{array}{l}2017 \\
\text { Pungtungia herzi } \\
\text { Zacco platypus } \\
\text { Acheilognathus majusculus } \\
\text { Acheilognathus yamatsutae } \\
\text { Zacco temminckii } \\
\text { Carassius auratus } \\
\text { Acanthorhodeus gracilis } \\
\text { Zacco koreanus } \\
\text { Coreoperca herzi } \\
\text { Squalidus japonicus coreanus } \\
\text { Hemibarbus labeo } \\
\text { Hemibarbus longirostris } \\
\text { Acheilognathus rhombeus } \\
\text { Acheilognathus koreensis } \\
\text { Squalidus gracilis majimae } \\
\text { Acanthorhodeus macropterus } \\
\text { Subtotal }\end{array}$ & $\begin{array}{r}53 \\
38 \\
37 \\
31 \\
30 \\
28 \\
21 \\
20 \\
18 \\
15 \\
8 \\
7 \\
7 \\
5 \\
3 \\
2 \\
323\end{array}$ & $\begin{aligned} & 24(45.3) \\
& 6(15.8) \\
& 27(73.0) \\
& 23(74.2) \\
& 6(20.0) \\
& 1(3.6) \\
& 10(47.6) \\
& 9(45.0) \\
& 1(5.6) \\
& 15(100) \\
& 2(25.0) \\
& 4(57.1) \\
& 3(42.9) \\
& 3(60.0) \\
& 1(33.3) \\
& 2(100) \\
& 137(42.4)\end{aligned}$ & $\begin{array}{l}1-73 \\
1-15 \\
1-52 \\
1-28 \\
1-7 \\
- \\
16-253 \\
1-14 \\
- \\
1-108 \\
2-5 \\
1-2 \\
4-50 \\
2-33 \\
- \\
8-9 \\
1-253\end{array}$ & $\begin{array}{r}12.9 \\
7.7 \\
14.9 \\
5.6 \\
3.0 \\
1.0 \\
57.1 \\
7.7 \\
1.0 \\
31.4 \\
3.5 \\
1.3 \\
24.0 \\
14.0 \\
1.0 \\
8.5 \\
15.8\end{array}$ \\
\hline Total & 1,578 & $811(51.4)$ & $1-253$ & 9.8 \\
\hline
\end{tabular}


Table 4. Infection status of Clinostomum complanatum metacercariae by the fish groups from Yangcheon in Sancheong-gun, Gyeongsangnam-do, Korea

\begin{tabular}{|c|c|c|c|c|}
\hline \multirow{2}{*}{ Fish examined } & \multirow{2}{*}{ No. of fish examined } & \multirow{2}{*}{ No. of fish infected (\%) } & \multicolumn{2}{|c|}{ No. of CcMc detected } \\
\hline & & & Range & Average \\
\hline Squalidus japonicus coreanus & 77 & $76(98.7)$ & $1-108$ & 23.6 \\
\hline Squalidus chankaensis & 51 & $51(100)$ & $1-143$ & 32.6 \\
\hline Squalidus gracilis majimae & 3 & $1(33.3)$ & - & 1.0 \\
\hline Subtotal & 131 & $128(97.7)$ & $1-143$ & 27.0 \\
\hline Hemibarbus longirostris & 77 & $20(26.0)$ & $1-7$ & 2.4 \\
\hline Hemibarbus labeo & 8 & $2(25.0)$ & $2-5$ & 3.5 \\
\hline Subtotal & 85 & $22(25.9)$ & $1-7$ & 2.5 \\
\hline Acheilognathus majusculus & 194 & $132(68.0)$ & $1-52$ & 7.9 \\
\hline Acheilognathus koreensis & 96 & $82(85.4)$ & $1-74$ & 7.6 \\
\hline Acheilognathus rhombeus & 35 & $23(65.7)$ & $1-50$ & 7.0 \\
\hline Acheilognathus yamatsutae & 58 & $41(70.7)$ & $1-28$ & 4.8 \\
\hline Acanthorhodeus gracilis & 41 & $15(36.6)$ & $1-253$ & 39.1 \\
\hline Acanthorhodeus macropterus & 19 & $3(15.8)$ & $1-9$ & 6.0 \\
\hline Subtotal & 443 & $296(66.8)$ & $1-253$ & 8.9 \\
\hline Zacco platypus & 190 & $80(42.1)$ & $1-22$ & 3.9 \\
\hline Zacco koreanus & 174 & $84(48.3)$ & $1-22$ & 3.6 \\
\hline Zacco temminckii & 91 & $16(17.6)$ & $1-12$ & 3.4 \\
\hline Subtotal & 455 & $180(39.6)$ & $1-22$ & 3.7 \\
\hline Pungtungia herzi & 333 & $173(52.0)$ & $1-73$ & 6.6 \\
\hline Carassius auratus & 70 & $7(10.0)$ & $1-5$ & 2.0 \\
\hline Coreoperca herzi & 48 & $3(6.3)$ & - & 1.0 \\
\hline Odontobutis platycephala & 13 & $2(15.4)$ & $5-10$ & 7.5 \\
\hline Total & 1,578 & $811(51.4)$ & $1-253$ & 9.8 \\
\hline
\end{tabular}

Table 5. Infection status of Clinostomum complanatum metacercariae by the fish species and survey area in the water systems of Nakdong-gang in the east coast of Korea

\begin{tabular}{|c|c|c|c|c|}
\hline \multirow{2}{*}{ Locality and fish sp. } & \multirow{2}{*}{ No. of fish examined } & \multirow{2}{*}{ No. of fish infected (\%) } & \multicolumn{2}{|c|}{ No. of CcMc detected } \\
\hline & & & Range & Average \\
\hline \multicolumn{5}{|l|}{ Whangpicheon in Uljin-gun } \\
\hline Pungtungia herzi & 47 & $3(6.4)$ & $2-6$ & 3.7 \\
\hline Squalidus gracilis majimae & 6 & $1(16.7)$ & - & 6.0 \\
\hline Subtotal & 53 & $4(7.6)$ & $2-6$ & 4.3 \\
\hline \multicolumn{5}{|l|}{ Osipcheon in Yeongdeok-gun } \\
\hline Squalidus gracilis majimae & 14 & $5(35.7)$ & $1-5$ & 2.2 \\
\hline \multicolumn{5}{|l|}{ Cheokgwacheon in Ulju-gun } \\
\hline Zacco temminckii & 50 & $1(2.0)$ & - & 1.0 \\
\hline Pungtungia herzi & 47 & $13(27.7)$ & $1-13$ & 3.8 \\
\hline Rhynchocypris oxycephalus & 20 & $1(5.0)$ & - & 3.0 \\
\hline Acheilognathus rhombeus & 20 & $5(25.0)$ & $1-4$ & 1.8 \\
\hline Acanthorhodeus gracilis & 17 & $7(41.2)$ & $3-9$ & 4.9 \\
\hline Zacco platypus & 15 & $2(13.3)$ & - & 1.0 \\
\hline Subtotal & 169 & $29(17.2)$ & $1-13$ & 3.4 \\
\hline \multicolumn{5}{|l|}{ Taehwa-gang in Ulju-gun } \\
\hline Carassius auratus & 14 & $1(7.1)$ & - & 1.0 \\
\hline Total & 250 & 39 (15.6) & $1-13$ & 3.3 \\
\hline
\end{tabular}


cheon in Sancheong-gun, Gyeongsangnam-do, Korea.

Two types of CcMc were reported in India. Non-encysted ones are usually found in the body cavity of Trichogaster fasciatus with high infection rates [22]. They are known to be the pathogenic agents in the viscera and musculature of many fish species [23]. Meanwhile, encysted ones are detected in the body cavitiy of Channa punctatus and they also act as the etiologic agents in their habitat organs of fish [24]. However, we only found noncysted CcMc in this study. Generally, we have been thought that the cyst wall of CcMc is so feeble and then it is easily bursted by the process of artificial digestion method. The further studies are needed whether CcMc is to be non-encysted or excysted in the digestion process of fish meat in Korea.

Several species of ardeiid birds have been reported as the natural definitive hosts of $C$. complanatum in the world. Even in Japan, C. complanatum adults were recovered from 4 species of wild birds, i.e., Nycticorax nycticorax, Ardea cinerea, Egretta garzetta, and E. intermedia, in Tottori prefecture [25]. However, only chick was proved as the experimental definitive host in Korea [9]. Accordingly, we should pay attention to the recovery of $C$. complanatum adults in the survey of wild birds.

More than 50 species have been reported as the members of genus Clinostomum by a variety of authors, even though their taxonomic validity is quite controversial. Among them, $C$. complanatum is the type-species and the most widely distributed in the world including Korea [3,9,20-24]. It is questionable that every Clinostomum specimens collected in various species of fish from various geographical areas of Korean peninsula are $\mathrm{CcMc}$, although specimens from human cases and experimental chick were already named as $C$. complanatum. The molecular study on the Clinostomum specimens from various origins should be carried out in the near future in Korea.

Conclusively, it is confirmed that the variety of fish species act as the second intermediate hosts of $C$. complanatum in the water systems of Nakdong-gang, and the endemicities of CcMc are more or less different by the fish group and species from Yangcheon, most endemic area, in Sancheong-gun, Gyeongsangnam-do, Korea.

\section{ACKNOWLEDGMENTS}

This study was supported by an anti-communicable diseases control program, 2014 and 2015 (Investigation of fish-borne parasites and acquisition of their biological resources in the southern and eastern regions of Korea) of National Institute of
Health (NIH), Korea Centers for Disease Control and Prevention (KCDCP), and a grant from Korea Association of Health Promotion (KAHP-2017: Survey on the effects of migratory bird in the infection status of trematode metacercariae in fish from Junam Reservoir). We thank Jung-A Kim and Hee-Joo Kim (Department of Parasitology and Tropical Medicine, Gyeongsang National University College of Medicine, Jinju, Korea), for their help in the examination of fish.

\section{CONFLICT OF INTEREST}

The authors have no conflicts of interest concerning the work reported in this paper.

\section{REFERENCES}

1. Kitagawa N, Oda M, Totoki T, Washizaki S, Oda M, Kifune T. Lidocaine spray used to capture a live Clinostomum parasite causing human laryngitis. Am J Otolaryngol 2003; 24: 341-343.

2. Hara H, MiyauchiY, Tahara S, YamashitaH. Human laryngitis caused by Clinostomum complanatum. Nagoya J Med Sci 2014; 76: 181-185.

3. Chung DI, Moon CH, Kong HH, Choi DW, Lim DK. The first human case of Clinostomum complanatum (Trematoda: Clinostomidae) infection in Korea. Korean J Parasitol 1995; 33: 219-223.

4. Park CW, Kim JS, Joo HS, Kim J. A human case of Clinostomum complanatum infection in Korea. Korean J Parasitol 2009; 47: 401-404.

5. Jung SC, Oh HJ, Kim DM, Park JH. A case of pharyngitis caused by Clinostomum complanatum. Korean J Otorhinolaryngol-Head Neck Surg 2015; 58: 61-63 (in Korean).

6. Lee GS, Park SW, Kim J, Seo KS, You KW, Chung JH, Moon HC, Hong GY. A case of endoscopically treated laryngopharyngitis resulting from Clinostomum complanatum infection. Korean J Gastroenterol 2017; 69: 177-180.

7. Song HB, Choi MH, Chung EJ. Human laryngeal infection by Clinostomum complanatum. Am J Trop Med Hyg 2018; 98: 7-8.

8. Kim HJ, Cho SW, Oh HR, Byeon HK. A case of unexpected Clinostomum complanatum infection initially presenting as foreign body in pharynx. Korean J Parasitol 2019; 57: 175-177.

9. Chung DI, Kong HH, Moon CH. Demonstration of the second intermediate hosts of Clinostomum complanatum in Korea. Korean J Parasitol 1995; 33: 305-312.

10. Chung DI, Kong HH, Joo CY. Radix auricularia coreana: Natural snail host of Clinostomum complanatum in Korea. Korean J Parasitol 1998; 36: 1-6.

11. Rim HJ, Kim KH, Joo KH, Kim SJ, Eom KS, Chung MS. The infestation status and changing patterns of human infecting metacercariae in freshwater fish in Kyongsang-do and Kyonggi-do, Korea. Korean J Parasitol 1996; 34: 95-105. 
12. Sohn WM, Na BK, Cho SH, Lee SW, Choi SB, Seok WS. Trematode metacercariae in freshwater fish from Water Systems of Hantangang and Imjingang in Republic of Korea. Korean J Parasitol 2015; 53: 289-298.

13. Sohn WM, Na BK, Cho SH, Park MY, Kim CH, Hwang MA, No KW, Yoon KB, Lim HC. Prevalence of Clonorchis sinensis metacercariae in fish from water systems of Seomjin-gang (River). Korean J Parasitol 2017; 55: 305-312.

14. Sohn WM, Na BK, Cho SH, Ju JW, Son DC. Prevalence and intensity of Clonorchis sinensis metacercariae in freshwater fish from Wicheon Stream in Gunwi-gun, Gyeongsangbuk-do, Korea. Korean J Parasitol 2018; 56: 41-48.

15. Yoon KB, Lim HC, Jeon DY, Park S, Cho SH, Ju JW, Shin SS, Na $\mathrm{BK}$, Sohn WM. Infection status with Clonorchis sinensis metacercariae in fish from Tamjin-gang (River) in Jeollanam-do, Republic of Korea. Korean J Parasitol 2018; 56: 183-188.

16. Sohn WM, Na BK, Cho SH, Ju JW, Kim CH, Yoon KB. Infection status with Metagonimus spp. metacercariae in fishes from Seomjin-gang and Tamjin-gang in Republic of Korea. Korean J Parasitol 2018; 56: 351-358.

17. Sohn WM, Na BK, Cho SH, Ju JW, Lee SW, Seok WS. Infections with zoonotic trematode metacercariae in yellowfin goby, Acanthogobius flavimanus, from coastal areas of Republic of Korea. Korean J Parasitol 2018; 56: 259-265.

18. Sohn WM, Na BK, Cho SH, Lee WJ. Prevalence and density of digenetic trematode metacercariae in clams and oysters from western coastal regions of the Republic of Korea. Korean J Parasitol 2017; 55: 399-408.

19. Sohn WM, Na BK, Cho SH, Ju JW. Infection status of Isthmiophora hortensis metacercariae in dark sleepers, Odontobutis species, from some water systems of the Republic of Korea. Korean J Parasitol 2018; 56: 633-637.

20. Sohn WM. Fish-borne zoonotic trematode metacercariae in the Republic of Korea. Korean J Parasitol 2009; 47 (suppl): 103-113.

21. Aohagi Y, Shibahara T, Machida N, Yamaga Y, Kagota K. Clinostomum complanatum (Trematoda: Clinostomatidae) in five new fish hosts in Japan. J Wildl Dis 1992; 28: 467-469.

22. Siddiqui AA, Nizami WA. Seasonal population dynamics of the metacercariae of Clinostomum complanatum (Trematoda: Digenea) in relation to sex of the host. Riv Parasitol 1982; 43: 275279.

23. Kalantan AMN, Arfin M, Nizami WA. Seasonal incidence and pathogenicity of the metacercariae of Clinostomum complanatum in Aphanius dispar. Jpn J Parasitol 1988; 36: 17-23.

24. Shareef PA, Abidi S. Incidence and histopathology of encysted progenetic metacercaria of Clinostomum complanatum (Digenea: Clinostomidae) in Channa punctatus and its development in experimental host. Asian Pac J Trop Biomed 2012; 2: 421-426.

25. Aohagi Y, Shibahara T, Machida N, Yamaga Y, Kagota K, Hayashi T. Natural infections of Clinostomum complanatum (Trematoda: Clinostomatidae) in wild herons and egrets, Tottori Prefecture, Japan. J Wildl Dis 1992; 28: 470-471. 
